\title{
INFLUENCE OF PRESCRIBED BURNING ON BIRD ABUNDANCE AND SPECIES ASSEMBLAGE IN A SEMIARID GREAT PLAINS GRASSLAND
}

\author{
Ashley M. Longl,3, William E. Jensen ${ }^{1}$, and Raymond S. Matlack ${ }^{2}$
}

\begin{abstract}
AвSTRACT.-Encroachment of woody plants is widespread in semiarid grasslands of the southwestern United States. Wildlife responses to shrub removal techniques in the region are relatively unknown. In 2008 and 2009, we examined avian responses to prescribed burning of ungrazed shortgrass prairie within a study area (4811 ha) near Amarillo, Texas, that is heavily encroached by honey mesquite (Prosopis glandulosa) and cholla (Opuntia spp.). Specifically, we compared relative abundance, species richness, and species diversity of breeding birds across large, spatially replicated experimental plots burned every 2 or 4 years since 2002 and unburned controls. We found no significant differences in the mean relative abundance of most species across the treatments. However, Northern Bobwhite (Colinus virginianus), Cassin's Sparrow (Peucaea cassinii), and Brown-headed Cowbird (Molothrus ater) were more abundant in less frequently burned plots and unburned controls. We found no differences in species richness or diversity across the treatments. Limited variation in avian responses across the treatments likely reflects the uniform pattern of vegetation structure we found across the plots, despite repeated application of prescribed fire at 2- and 4-year intervals over a 7-year period. Differences in bird species assemblages among the burn treatments might be more prominent in future years as prescribed burning continues.
\end{abstract}

RESUMEn.-En las praderas semiáridas del suroeste de los Estados Unidos se ha extendido la invasión de plantas leñosas. La respuesta de la vida silvestre a las técnicas de eliminación de arbustos en la región es relativamente desconocida. En 2008 y 2009, examinamos la respuesta de las aves a la quema controlada de praderas sin pastar y de hierba corta dentro de un área de estudio (4.811 ha) fuertemente invadida por miel de mezquite (Prosopis glandulosa) y cactus cholla (Opuntia spp.) cerca de Amarillo, Texas, Estados Unidos. Específicamente, comparamos la abundancia relativa, la riqueza de especies y la diversidad de especies de aves en reproducción a lo largo de parcelas experimentales grandes, replicadas espacialmente, quemados cada 2 o 4 años desde 2002, y controles sin quemar. No encontramos ninguna diferencia significativa en la abundancia promedio relativa de la mayoría de las especies a través de los tratamientos. Sin embargo, la Codorniz Norteña (Colinus virginianus), el Gorrión de Cassin (Peucaea cassinii) y el Tordo de Cabeza Marrón (Molothrus ater) eran más abundantes en terrenos quemados con menor frecuencia y en controles sin quemar. No encontramos ninguna diferencia ni en la riqueza ni en la diversidad de especies a través de los tratamientos. La limitada variación en las respuestas de las aves a través de los tratamientos probablemente refleja el esquema uniforme de la estructura de la vegetación que encontramos a través de los terrenos, a pesar de la repetida quema controlada en intervalos de 2 y 4 años durante un período superior a siete años. Las diferencias en el ensamble de especies de aves en los tratamientos de quemado podrían ser más importantes en años futuros si continúan los incendios controlados.

In the Great Plains region of the United States, changes in land use accompanying European settlement resulted in the loss, fragmentation, and degradation of native grasslands (Samson and Knopf 1994, Samson et al. 2004). Grassland bird populations concurrently declined in this biogeographic region (Peterjohn and Sauer 1999, Butcher and Niven 2007), stimulating an abundance of research on the effects of habitat loss, degradation, and restoration on grassland birds (Herkert et al. 1996, Brawn et al. 2001, Vickery and Herkert 2001, With et al. 2008). Much of this research has been conducted on birds that utilize tallgrass prairie during some portion of their life cycle. As a result, avian responses to alterations and management of native tallgrass prairie are relatively well known (Askins et al. 2007). Fewer studies have examined such relationships in other prairie ecoregions of the Great Plains, where similar bird population declines have been observed (Peterjohn and Sauer 1999, Samson et al. 2004, Butcher and Niven 2007).

As with tallgrass prairie, the spatial extent of shortgrass prairie decreased with advancing conversion of grasslands to croplands in the Great Plains (Samson and Knopf 1994, Samson et al. 2004). Reduction in the extent of shortgrass

\footnotetext{
${ }^{1}$ Department of Biological Sciences, Emporia State University, Emporia, KS 66801.

${ }^{2}$ Department of Life, Earth and Environmental Sciences, West Texas A\&M University, Canyon, TX 79016.

${ }^{3}$ Present address: Texas A\&M Institute of Renewable Natural Resources, 1500 Research Parkway, Suite 110, 2260 TAMU, College Station, TX 77843-2260. E-mail: ashley.long@ag.tamu.edu
} 
TABLE 1. Detections of bird species ( $\mathrm{X}=$ detected, otherwise not detected) across 2 prescribed burn treatments (fire every 2 or 4 years) and unburned controls at the Cross Bar Cooperative Management Area, located near Amarillo, Texas, 2008-2009.

\begin{tabular}{|c|c|c|c|c|}
\hline \multirow[b]{2}{*}{ Common name } & \multirow[b]{2}{*}{ Scientific name } & \multicolumn{3}{|c|}{ Treatment } \\
\hline & & 2 & 4 & Control \\
\hline Scaled Quail & Callipepla squamata & $\mathrm{X}$ & & $\mathrm{X}$ \\
\hline Northern Bobwhite & Colinus virginianus & $\mathrm{X}$ & $\mathrm{X}$ & $\mathrm{X}$ \\
\hline Mourning Dove & Zenaida macroura & $\mathrm{X}$ & $\mathrm{X}$ & $\mathrm{X}$ \\
\hline Great Horned Owl & Bubo virginianus & & & $\mathrm{X}$ \\
\hline Ladder-backed Woodpecker & Picoides scalaris & & $\mathrm{X}$ & $\mathrm{X}$ \\
\hline Ash-throated Flycatcher & Myiarchus cinerascens & $\mathrm{X}$ & $\mathrm{X}$ & $\mathrm{X}$ \\
\hline Western Kingbird & Tyrannus verticalis & & & $\mathrm{X}$ \\
\hline Scissor-tailed Flycatcher & Tyrannus forficatus & $\mathrm{X}$ & $\mathrm{X}$ & \\
\hline Loggerhead Shrike & Lanius ludovicianus & & $\mathrm{X}$ & $\mathrm{X}$ \\
\hline Bewick's Wren & Thryomanes bewickii & $\mathrm{X}$ & $\mathrm{X}$ & $\mathrm{X}$ \\
\hline Cactus Wren & Campylorhynchus brunneicapillus & $\mathrm{X}$ & $\mathrm{X}$ & $\mathrm{X}$ \\
\hline Curve-billed Thrasher & Toxostoma curvirostre & $\mathrm{X}$ & $\mathrm{X}$ & $\mathrm{X}$ \\
\hline Northern Mockingbird & Mimus polyglottos & $\mathrm{X}$ & $\mathrm{X}$ & $\mathrm{X}$ \\
\hline Canyon Towhee & Melozone fusca & & $\mathrm{X}$ & $\mathrm{X}$ \\
\hline Cassin's Sparrow & Peucaea cassinii & $\mathrm{X}$ & $\mathrm{X}$ & $\mathrm{X}$ \\
\hline Lark Sparrow & Chondestes grammacus & $\mathrm{X}$ & $\mathrm{X}$ & $\mathrm{X}$ \\
\hline Grasshopper Sparrow & Ammodramus savannarum & & $\mathrm{X}$ & \\
\hline Northern Cardinal & Cardinalis cardinalis & $\mathrm{X}$ & & \\
\hline Blue Grosbeak & Passerina caerulea & $\mathrm{X}$ & $\mathrm{X}$ & $\mathrm{X}$ \\
\hline Indigo Bunting & Passerina cyanea & & & $\mathrm{X}$ \\
\hline Painted Bunting & Passerina ciris & $\mathrm{X}$ & & $\mathrm{X}$ \\
\hline Western Meadowlark & Sturnella neglecta & $\mathrm{X}$ & $\mathrm{X}$ & $\mathrm{X}$ \\
\hline Brown-headed Cowbird & Molothrus ater & $\mathrm{X}$ & $\mathrm{X}$ & $\mathrm{X}$ \\
\hline Bullock's Oriole & Icterus bullockii & $\mathrm{X}$ & $\mathrm{X}$ & $\mathrm{X}$ \\
\hline House Finch & Haemorhous mexicanus & $\mathrm{X}$ & $\mathrm{X}$ & $\mathrm{X}$ \\
\hline
\end{tabular}

prairie contributed to population declines in birds associated with this vegetation type. More recently, the degradation of remaining shortgrass prairie has influenced associated bird populations (Askins et al. 2007). Degradation is most pronounced in the arid southwestern Great Plains, where fire suppression and overgrazing have converted semiarid grasslands to shrubsteppes that are dominated by woody species, such as mesquite (Prosopis spp.), salt cedar (Tamarix spp.), and creosotebush (Larrea tridentata) (Archer 1989, Bahre 1991, 1995, Bahre and Shelton 1993, Van Auken 2000). Widespread encroachment of honey mesquite (Prosopis glandulosa) is of particular concern, as this species now covers more than 38 million ha that was previously classified as shortgrass prairie in this region (Archer 1989, Van Auken 2000, Brockway et al. 2002). Populations of several bird species, such as Scaled Quail, Northern Bobwhite, Cassin's Sparrow, Lark Sparrow, and Western Meadowlark, have simultaneously declined in the southwest (Peterjohn and Sauer 1999, Butcher and Niven 2007; see Table 1 for scientific names of birds). Preservation and restoration of remaining semiarid shortgrass prairie is essential to grassland bird conservation in the Great Plains.

Prescribed burning may increase graminoid production, reverse shrub encroachment, and limit further afforestation in semiarid grassland (Cable 1967, Britton and Wright 1971, Heirman and Wright 1973, Medina and Silva 1990, Williams et al. 1999, Roques et al. 2001). However, the use of fire as a management tool in the southwestern United States is limited by uncertainty regarding seasonal and historic fire frequencies, nutrient turnover rates, slow regrowth of vegetation following fire events, and resistance to burning by private landowners (Wright and Bailey 1982, Brockway et al. 2002). As such, few studies have experimentally examined avian responses to prescribed burning in semiarid shortgrass prairie (Ford and McPherson 1996, Brawn et al. 2001, Bock and Block 2005). Short-term unreplicated research suggests that the abundances of some grassland-nesting bird species increase in the years immediately following the reintroduction of fire (Bock and Bock 1992, Kirkpatrick et al. 2002). Other studies reported no observable change in 
postdisturbance bird abundances (Reynolds and Krausman 1998).

Avian community-level responses to fire in semiarid grasslands of the southwest are similarly unclear. As in tallgrass (e.g., Zimmerman 1992, Fuhlendorf et al. 2006, Coppedge et al. 2008) and mixed-grass prairies (e.g., Grant et al. 2010), avian species richness in shortgrass may be lower in the year immediately following a prescribed burn and may increase over time as a result of increasing structural heterogeneity (Roberts et al. 2012). Thus, avian species richness and diversity may be lower in more frequently burned shortgrass prairie if prescribed burning maintains or restores grassland conditions. However, other studies reported no difference in species richness between burned and unburned semiarid grasslands (Reynolds and Krausman 1998). With such contrasting results, habitat managers have limited predictability of bird responses to fire in the southwestern Great Plains; thus, appropriate prescribed-burning management for restorative purposes is relatively unknown (Brockway et al. 2002, Bock and Block 2005, Askins et al. 2007).

We examined avian responses to prescribed burning of semiarid shortgrass prairie in the southern Great Plains of North America. We compared species-specific relative abundance, species richness, and species diversity of birds across large experimental plots burned every 2 or 4 years since 2002 and unburned controls. Our study area was heavily encroached by honey mesquite and cholla (Opuntia spp.), as typically found in the southwestern United States. We predicted that the abundances of grassland-nesting bird species would increase with increasing fire frequency and that the number of bird species would be greatest in our unburned controls.

\section{METHODS}

\section{Study Area}

We conducted our research during the 2008 (18 May-31 July) and 2009 (17 May-31 July) breeding seasons. Our study area was located approximately $20 \mathrm{~km}$ northwest of Amarillo, Texas $\left(35^{\circ} \mathrm{N}, 101^{\circ} \mathrm{W}\right)$ at the 4811 -ha Cross Bar Cooperative Management Area (CCMA). Average monthly temperatures and monthly precipitation from May to July in the years 1971-2000 ranged from 18.0 to $26.0{ }^{\circ} \mathrm{C}$ and 6.4 to $8.3 \mathrm{~cm}$ (NWS 2009). Average monthly temperatures and precipitation ranged from 19.1 to $25.2{ }^{\circ} \mathrm{C}$ and 5.3 to $12.6 \mathrm{~cm}$ during data collection in 2008 (NWS 2009). During the 2009 field season, average monthly temperatures and precipitation ranged from 17.7 to $25.6{ }^{\circ} \mathrm{C}$ and 1.1 to $9.6 \mathrm{~cm}$ (NWS 2009).

The CCMA was historically composed of graminoid species common to semiarid shortgrass prairie, such as blue grama (Bouteloua gracilis), hairy grama (Bouteloua hirsuta), and buffalo grass (Buchloe dactyloides). These grass species remain abundant at the CCMA. However, as found consistently across the southwestern United States, fire suppression $(>100$ years) and extensive overgrazing by domestic cattle (Bos taurus) (70 years; grazers were mostly removed in 1993 and completely removed by 1998) resulted in the widespread encroachment of honey mesquite and cholla. In 2002, the U.S. Bureau of Land Management (BLM), in cooperation with West Texas A\&M University (WTAMU), established 9 experimental units (120-220 ha; hereafter "plots") on the CCMA to examine the effect of prescribed burning on shrub density. Each plot was assigned a burn treatment (i.e., fire every 2,4 , or 10 years) in a stratified, random design, with 3 plot replicates of each burn treatment.

In 2008 , plots burned every 2 years had experienced 3 prescribed burns since 2002 (i.e., 2002, 2004, 2006) and were in the second growing season since the last prescribed burn (a burn ban prevented application of fire to the 2-year burn plots in 2008). Plots burned every 4 years had experienced 2 prescribed burns since 2002 (i.e., 2002, 2006) and were in the third growing season since the last prescribed burn, which was conducted in the winter of 2006. In 2009 (after the burn ban was lifted), land managers conducted prescribed burns on plots assigned to receive prescribed burns every 2 years. Therefore, during the 2009 breeding bird season, plots that were burned every 2 years were in the first growing season since the last prescribed burn in the winter of 2009 , and plots that were burned every 4 years were in the fourth growing season since the last prescribed burn in 2006. Though designated in the experimental design as plots burned every 10 years, the 10year burn replicates had not yet been treated and there are no records of prescribed burning or wildfire on these plots at the time of our 
TABLE 2. Comparison of mean vegetation variables across plots treated with prescribed fire every 2 and 4 years and unburned controls at the Cross Bar Cooperative Management Area located near Amarillo, Texas, during 2008-2009. Means are listed separately per year where interactions between burn treatment and year were statistically significant. Standard errors are in parentheses. Reproduced from Long et al. (2012) with permission from John Wiley \& Sons, Inc.

\begin{tabular}{|c|c|c|c|c|c|c|}
\hline \multirow[b]{2}{*}{ Habitat variable } & \multicolumn{6}{|c|}{ Burn treatment } \\
\hline & 2 & & 4 & & Control & \\
\hline \multicolumn{7}{|l|}{ Herbaceous plant height $(\mathrm{cm})$} \\
\hline $2008^{* *}$ & $11.0(1.00)$ & a & $11.3(2.84)$ & $\mathrm{a}$ & $18.7(2.73)$ & $\mathrm{b}$ \\
\hline $2009^{*}$ & $9.2(0.73)$ & $\mathrm{a}$ & $32.7(4.81)$ & $\mathrm{b}$ & $34.3(6.57)$ & $\mathrm{b}$ \\
\hline \multicolumn{7}{|l|}{ Percent grass cover* } \\
\hline $2008^{*}$ & $64.8(1.48)$ & a & $63.0(3.13)$ & $\mathrm{a}$ & $74.4(1.62)$ & $\mathrm{b}$ \\
\hline $2009^{*}$ & $61.6(0.19)$ & $\mathrm{a}$ & $76.8(0.80)$ & $\mathrm{b}$ & $77.4(3.25)$ & $\mathrm{b}$ \\
\hline Percent forb cover & $10.5(1.60)$ & & $12.3(0.63)$ & & $16.2(0.74)$ & \\
\hline \multicolumn{7}{|l|}{ Percent bare ground } \\
\hline $2008^{*}$ & $35.2(1.48)$ & a & $37.0(1.67)$ & $\mathrm{a}$ & $25.6(0.52)$ & $\mathrm{b}$ \\
\hline $2009^{*}$ & $38.3(0.21)$ & a & $22.9(0.84)$ & $\mathrm{b}$ & $22.1(3.35)$ & $\mathrm{b}$ \\
\hline All shrub density & $683.3(123.90)$ & & $532.4(105.13)$ & & $627.8(159.87)$ & \\
\hline Large shrub density** & $95.4(9.76)$ & $\mathrm{ab}$ & $65.7(9.86)$ & $\mathrm{a}$ & $118.2(21.62)$ & $\mathrm{b}$ \\
\hline Small shrub density & $490.6(87.09)$ & & $385.1(71.79)$ & & $355.2(63.02)$ & \\
\hline Mesquite density & $313.8(31.73)$ & & $256.0(28.16)$ & & $316.0(66.11)$ & \\
\hline Large mesquite density & $8.0(1.98)$ & & $8.5(3.68)$ & & $17.0(4.58)$ & \\
\hline Small mesquite density & $43.8(6.31)$ & & $52.3(4.79)$ & & $60.0(11.14)$ & \\
\hline Large top-killed mesquite density** & $48.8(6.26)$ & $\mathrm{ab}$ & $29.8(4.79)$ & $\mathrm{a}$ & $57.4(11.89)$ & $\mathrm{b}$ \\
\hline Small top-killed mesquite density & $91.3(14.75)$ & & $86.3(16.27)$ & & $62.7(5.80)$ & \\
\hline Cholla density & $138.2(31.83)$ & & $100.7(36.89)$ & & $111.5(26.02)$ & \\
\hline Large cholla density & $18.5(5.83)$ & & $14.3(1.65)$ & & $21.0(2.85)$ & \\
\hline Small cholla density & $93.8(21.92)$ & & $81.0(31.36)$ & & $73.3(12.29$ & \\
\hline
\end{tabular}

aWe recorded habitat measurements within each $100 \mathrm{~m}$ radius circle surveyed to estimate species-specific relative abundance, species richness, and species diversity. Details regarding sampling methodology and analysis can be found in Long et al. 2012.

${ }^{\mathrm{b}}$ Mesquite and cholla density (stems $\left.\cdot \mathrm{ha}^{-1}\right)$ categories: large $(\geq 1.5 \mathrm{~m}$ tall), small $(<1.5 \mathrm{~m}$ tall), live and top-killed (i.e., basal regrowth following fire) mesquite, all shrubs (across species and size classes), large shrubs (both species), small shrubs (both species), all mesquite (both size classes and structures), and all cholla (both size classes). 'Significantly different means $\left(^{*}\right)$ are indicated with different letters when overall $P$ values indicate a statistically significant difference $(P<0.05)$ across the burn treatments. Marginally significant means $\left.{ }^{* * *}\right)$ are also indicated with different letters when $0.05 \leq P \leq 0.10$

study. As such, they served as unburned controls for the present study but are expected to be used as 10-year replicates for future studies conducted at the CCMA.

In 2008 and 2009, we measured herbaceous plant height, estimated percent horizontal coverages of grasses, forbs, and bare ground, and measured several categories $(\geq 1.5 \mathrm{~m}$ tall, live vs. top-killed shrubs, etc.) of mesquite and cholla densities across the experimental units as part of a related study (Long et al. 2012). In general, herbaceous cover responded negatively to increasing burn frequency, but prescribed burning had few clear effects on shrub density (Table 2). The densities of large shrubs (i.e., all shrub species combined) and large top-killed mesquite were higher in unburned controls, but there were no statistically significant differences in the densities of these 2 shrub categories between plots burned every 2 years and unburned controls or between plots burned every 2 years and plots burned every 4 years (Table 2). Prescribed burning had no effect on the density of any other shrub category included in our analyses (Table 2).

\section{Bird Surveys}

We measured bird abundance using pointcount sampling. We surveyed birds within 100 $m$ fixed-radius point-count circles. These were systematically spaced within each plot to provide uniform plot coverage, where count-circle perimeters were at least $200 \mathrm{~m}$ apart and at least $100 \mathrm{~m}$ from plot boundaries, to minimize the risk of recounting individuals or counting individuals that had territories outside our plot boundaries. The number of point-count circles within each plot depended on the total area of the plot and ranged from 4 to 11 points per plot. Across the 3 replicates per treatment, this resulted in 30 point-count circles located within plots burned every 2 years, 34 pointcount circles located within plots burned every 4 years, and 44 point-count circles located within the unburned controls.

Each point-count circle was surveyed by a single observer 3 times per breeding season (23 May-25 June 2008; 19 May-22 June 2009) for 5 minutes in the morning from about 06:30 to 09:00. Surveys were not conducted during 
periods of heavy rainfall. Wind speed was consistently high (range $0-30.4 \mathrm{~km} \cdot \mathrm{h}^{-1}$ ) throughout the field season; therefore, we used the maximum number of birds (per species and year) detected per point-count circle for calculations of species-specific relative abundance (Bibby et al. 2000). We alternated the order of visitation among survey points per plot to account for diel variation in bird activity. During surveys, we recorded all birds seen or heard within $100 \mathrm{~m}$ of each survey point. We did not include flyover detections in our analyses.

For all species but Brown-headed Cowbirds, we estimated species-specific relative abundance by dividing the maximum number of singing male birds observed per circle per year by the area of our $100 \mathrm{~m}$ radius pointcount circles (3.14 ha). We estimated the relative abundance of Brown-headed Cowbirds similarly, but pooled male and female observations given that this species is a brood parasite of many songbirds in the focal avian community. Relative abundance (individuals counted per hectare) per species was averaged across points per plot, where means per plot were used as replicates in analyses. This was done for species where $>30$ individuals were recorded across plots and years.

Our goal was to examine relative differences in avian abundance across specific treatment types, not to estimate species-specific density. Therefore, we compared actual counts per hectare of singing males rather than accounting for imperfect detectability, which can introduce analytical constraints (e.g., sample size of counts per species) and uncertainty when indices adequately address the research question of interest (Johnson 2008). Our previous analysis of these data using program DISTANCE (Buckland et al. 2001, Thomas et al. 2006) that corrected for imperfect detectability yielded similar results as our relative abundance estimates (Long 2010). We suspect that detectability was uniform and close to 1 across the treatments due to similarities in arboreal vegetation structure across plots (Long et al. 2012; Table 2).

To characterize species assemblage, we calculated species richness $(S)$ as the total number of species detected per circle per year, and then averaged $S$ across circles per plot for each year. We also calculated Shannon-Wiener species diversity indices $\left(H^{\prime}\right)$ using the maximum number of species observed per circle and the maximum number of individuals observed per species for each circle, by year. We then averaged $H^{\prime}$ values across circles per plot for each year.

\section{Statistical Analysis}

We used a 2-way ANOVA performed in $\mathrm{R}$ software (R Development Core Team 2011) to compare male relative abundance, species richness, and species diversity among the treatments (i.e., burning every 2 years, burning every 4 years, or unburned controls) between years, as well as to test for interactions between treatment and year. When the additive effects of treatment and year or the interactions between treatment and year were not statistically significant, we used one-way ANOVAs with the single treatment effect (with plot-level data averaged across years) to examine variation in relative abundance, species richness, and species diversity among the treatments. When ANOVAs indicated significant differences among means, we used Tukey's multiple comparison tests for pairwise comparisons of means among treatments. For all analyses, we used a traditional $\alpha=0.05$ to demarcate statistical significance but also noted where biological differences may be evident with marginal $P$ values $(0.05<P<$ 0.1 ), as $\alpha$ is arbitrary (Johnson 1999).

\section{RESULTS}

We recorded 25 bird species across the 9 plots during surveys conducted in 2008 and 2009 (Table 1). The 5 most common species were Cassin's Sparrow (278 detections), Northern Mockingbird (238 detections), Lark Sparrow (220 detections), Western Meadowlark (101 detections), and Northern Bobwhite (68 detections). These species accounted for $77 \%$ of our total detections and we observed these species in all plots.

Based on the criterion of detection sample size $(n>30)$, we analyzed mean relative abundance for 9 species (Table 3). A single treatment effect was used to examine variation in relative abundance for all species but Northern Bobwhite and Cassin's Sparrow; abundances of the latter species also varied significantly between years. We found no significant differences in mean relative abundances of Mourning Dove, Cactus Wren, Northern Mockingbird, Curve-billed Thrasher, Lark Sparrow, and 
TABLE 3. Mean avian relative abundance, species richness, and species diversity across 2 prescribed burn treatments (fire every 2 or 4 years) and unburned controls at the Cross Bar Cooperative Management Area, located near Amarillo, Texas, 2008-2009. Standard errors are in parentheses.

\begin{tabular}{|c|c|c|c|c|c|c|}
\hline & \multicolumn{6}{|c|}{ Treatment $^{\mathrm{a}}$} \\
\hline & 2 & 4 & & Control & $F$ & $P$ \\
\hline \multicolumn{7}{|l|}{ Abundance $^{b}$} \\
\hline Northern Bobwhite & $0.10(0.03) \mathrm{a}$ & $0.15(0.05)$ & a & $0.22(0.04) \quad b$ & 3.44 & 0.06 \\
\hline Mourning Dove & $0.07(0.03)$ & $0.10(0.05)$ & & $0.12(0.03)$ & 0.31 & 0.74 \\
\hline Cactus Wren & $0.10(0.01)$ & $0.09(0.02)$ & & $0.16(0.06)$ & 1.16 & 0.31 \\
\hline Northern Mockingbird & $0.42(0.03)$ & $0.40(0.05)$ & & $0.50(0.04)$ & 0.87 & 0.44 \\
\hline Curve-billed Thrasher & $0.12(0.03)$ & $0.06(0.03)$ & & $0.05(0.03)$ & 1.52 & 0.25 \\
\hline \multicolumn{7}{|l|}{ Cassin's Sparrow } \\
\hline 2008 & $0.43(0.03)$ & $0.43(0.11)$ & & $0.63(0.04)$ & 0.88 & 0.13 \\
\hline 2009 & $0.20(0.11)$ a & $0.60(0.06)$ & $b$ & $0.64(0.04) \quad b$ & 9.42 & 0.01 \\
\hline Lark Sparrow & $0.42(0.08)$ & $0.47(0.04)$ & & $0.39(0.04)$ & 0.59 & 0.57 \\
\hline Western Meadowlark & $0.15(0.07)$ & $0.26(0.06)$ & & $0.24(0.10)$ & 0.54 & 0.60 \\
\hline Brown-headed Cowbird & $0.03(0.03) \quad \mathrm{a}$ & $0.12(0.05)$ & $\mathrm{ab}$ & $0.18(0.04) \mathrm{b}$ & 3.36 & 0.06 \\
\hline Species richness & $5.86(0.34)$ & $6.14(0.25)$ & & $6.53(0.43)$ & 0.91 & 0.42 \\
\hline Species diversity & $1.55(0.07)$ & $1.59(0.05)$ & & $1.68(0.09)$ & 0.89 & 0.43 \\
\hline
\end{tabular}

aSignificantly different means are indicated with different letters when $P<0.10$ across the treatments.

bdf for all avian response variables but $\mathrm{NOBO}$ and $\mathrm{CASP}=2,15$; $\mathrm{df} \mathrm{NOBO}=2,14$; $\mathrm{df}$ CASP $=2,12$.

Western Meadowlark across the treatments (Table 3). Mean relative abundance of Northern Bobwhite was highest in unburned controls and lowest in plots burned every 2 years, though the statistical significance was marginal (Table 3). Mean relative abundance of Northern Bobwhite was significantly lower in 2008 than in 2009 $\left(F_{2,14}=10.79, P<0.01\right)$. There was a marginally significant interaction between treatment and year for relative abundance of Cassin's Sparrow $\left(F_{2,12}=3.79, P=0.05\right)$. In 2008, treatment had no significant effect on mean Cassin's Sparrow relative abundance, but in 2009 mean Cassin's Sparrow relative abundance was significantly higher in plots burned every 4 years and in unburned control plots than in plots burned every 2 years (Table 3 ). The difference in mean relative abundance of Brown-headed Cowbirds was marginally significant, with mean relative abundance highest in unburned control plots and lowest in plots burned every 2 years. However, there was no significant difference in the mean relative abundance of Brown-headed Cowbird in plots burned every 4 years and unburned control plots or in plots burned every 2 years and every 4 years (Table 3). We found no significant difference in mean species richness or mean species diversity of birds across the treatments (Table 3 ).

\section{Discussion}

We predicted that the abundances of grassland-nesting bird species would increase with increasing fire frequency and that species richness and species diversity would be greatest in our unburned controls. Consistent with widespread shrub encroachment in the southwestern Great Plains, and with avian research conducted in semiarid grasslands of the southwest (Bock and Bock 1992, Lloyd et al. 1998, Kirkpatrick et al. 2002), a majority of the species we observed on our study site are typically associated with some degree of woody vegetation (Table 1). Abundances of most species that met our criteria for analyses, including grassland-nesting species (e.g., Western Meadowlark), showed no differences across the treatments, and additionally we found no differences in species richness or diversity across the treatments (Table 3). The lack of patterns in our avian responses is likely due to the limited variation in woody vegetation structure across the plots (Table 2 ), despite repeated application of prescribed fire at 2- or 4-year intervals over a 7 -year period.

Three species did show differences in mean relative abundance across the experimental plots. Similar to results reported by Bock and Bock (1992), the abundance of Cassin's Sparrows was lowest immediately following the 2009 prescribed fire conducted in plots burned every 2 years and highest in plots burned every 4 years and in our unburned controls. While this sparrow may prefer more open habitat for foraging, its distribution across the treatments in 2009 may better reflect its affinity for taller herbaceous vegetation and greater grass 
coverage for nesting and the male's use of high perches for aerial territorial displays (Dunning et al. 1999). Northern Bobwhite abundance was also highest in unburned controls (Table 3 ). This pattern likely reflects the greater protective cover (Renwald et al. 1978, Carter et al. 2002, Ransom et al. 2008) and foraging opportunities (Jackson 1969) provided by large shrubs found in our unburned control plots, or as with Cassin's Sparrow, greater grass coverage for nesting cover. Thus, some degree of fire suppression might be beneficial for these grassland bird species-at least in terms of abundance- until woody encroachment entirely displaces herbaceous habitat.

Brown-headed Cowbirds are often associated with wooded plant communities over herbaceous communities (Lowther 1993, Robinson et al. 1999), and the mean relative abundance of cowbirds at our study site was highest on plots with no recent fire history. However, given similarities in shrub density in plots burned every 2 years and unburned controls (Table 2), we cannot directly attribute patterns of Brown-headed Cowbird abundance at the CCMA to shrub density or fire frequency. The pattern of cowbird abundance was also inconsistent with that of cowbird nest parasitism across the treatments (Long 2010), as most Lark Sparrow nests parasitized by Brown-headed Cowbirds at our study site were concentrated on a single plot with grazing livestock in a neighboring pasture that typified cowbird foraging habitat (Goguen and Mathews 2000). As such, the mechanisms driving patterns of cowbird abundance at our study site remain unclear.

Repeated application of fire at 2- and 4year intervals had little effect on shrub density at our study site, and we detected limited variation in avian responses across the treatments, though our study covered only 7 years since the reintroduction of fire to a previously firesuppressed landscape. If continued application of prescribed fire at regular intervals reduces overall mesquite and cholla density and creates or maintains open grassland conditions at the CCMA, we expect future studies to find differences in bird abundances, species richness, and species diversity across the burn treatments and unburned controls, as well as increases in grassland bird abundance in morefrequently burned plots. However, grassland restoration at our study site and other severely shrub-encroached semiarid grasslands of the southwest may not be possible without the use of (1) prescribed burns under conditions that increase fire intensity (e.g., high fuel loads, drought), (2) chemical or mechanical shrub removal, or (3) a combination of these techniques. Such land management practices are difficult to implement on sufficient spatial and temporal scales and may be socially resisted (Wright and Bailey 1982, Brockway et al. 2002, Yoder et al. 2003), but these practices likely provide the only opportunities to reverse current grassland bird abundance trends in this region. Managers and scientists should coordinate to design more grassland restoration efforts that allow for experimental research on vegetation and wildlife responses to shrub removal techniques, especially in the southwestern United States, where information necessary to guide land management is limited.

\section{ACKNOWLEDGMENTS}

Our research was funded by an Emporia State University (ESU) Research and Creativity Grant awarded to W. Jensen, an ESU Graduate Student Research Grant awarded to A. Long., and a Kansas Ornithological Society Student Research Award awarded to A. Long. Additional financial support for this project was provided by the BLM. We acknowledge B. Koerner, B. Thomas, and 2 anonymous reviewers for providing helpful comments on earlier drafts of this manuscript. We thank L. Eaton, S. Epting, M. Jacobson, and E. Tsakiris who assisted with data collection as part of the National Science Foundation Research Experience for Undergraduates program through WTAMU. We give special thanks to P. Tanner who assisted with coordination of our research with the BLM. We also thank all volunteers who contributed time and resources to this project.

\section{Literature Cited}

Archer, S. 1989. Have southern Texas savannas been converted to woodlands in recent history? American Naturalist 134:545-561.

Askins, R.A., F. Chavez-Ramirez, B.C. Dale, C.A. Haas, J.R. Herkert, F.L. KNOPF, AND P.D. Vickery. 2007. Conservation of grassland birds in North America: understanding ecological processes in different regions. Ornithological Monographs 64:1-46.

Bahre, C.J. 1991. A legacy of change: historic human impact on vegetation in the Arizona borderlands. University of Arizona Press, Tucson, AZ. 
1995. Human impacts on the grasslands of southeastern Arizona. Pages 230-236 in M.P. McClaran and T.R. Van Devender, editors, The desert grassland. University of Arizona Press, Tucson, AZ.

Bahre, C.J., AND M.L. Shelton. 1993. Historic vegetation change, mesquite increases, and climate in southeastern Arizona. Journal of Biogeography 20:489-504.

Bibby C.J., N.D. Burgess, D.A. Hill, and S.H. Mustoe. 2000. Bird census techniques. Academic Press, London.

Bock, C.E., AND J.H. Bock. 1992. Response of birds to wildfire in native versus exotic Arizona grassland. Southwestern Naturalist 37:73-81.

Bock, C.E., AND W.M. BLOCK. 2005. Fire and birds in the southwestern United States. Studies in Avian Biology 30:14-32.

Brawn, J.D., S. Robinson, and F.R. Thompson III. 2001. The role of disturbance in the ecology and conservation of birds. Annual Review of Ecological Systematics 32:251-276.

Britton, C.M., AND H.A. Wright. 1971. Correlation of weather and fuel variables to mesquite damage by fire. Journal of Range Management 24:136-141.

Brockway, D.G., R.G. Gatewood, and R.B. Paris. 2002. Restoring fire as an ecological process in shortgrass prairie systems: initial effects of prescribed burning during the dormant and growing seasons. Journal of Environmental Management 65:135-152.

BucKLand, S.T., D.R. ANDERSON, K.P. BuRnhaM, J.L. LAAKE, D.L. BorChers, AND L. ThOMAS. 2001. Introduction to distance sampling: estimating abundance of biological populations. Oxford University Press, Oxford, United Kingdom.

Butcher, G.S., AND D.K. Niven. 2007. Combining data from the Christmas Bird Count and Breeding Bird Survey to determine the continental status and trends of North American birds. Available from: http://www.audubon.org/bird/stateofthebirds/CBID/ content/Report.pdf

Cable, D.R. 1967. Fire effects on semiarid grasses and shrubs. Journal of Range Management 20:170-176.

Carter, P.S., D. Rollins, and C.B. ScotT. 2002. Initial effects of prescribed burning on survival and nesting success of bobwhite quail in west-central Texas. Pages 129-134 in Proceedings of the 5th National Quail Symposium. Texas Parks and Wildlife Department, Austin, TX.

Coppedge, B.R., S.D. Fuhlendorf, W.C. Harrell, and D.E. EngLe. 2008. Avian community responses to vegetation and structural features in grasslands managed with fire and grazing. Biological Conservation 141:1196-1203.

Dunning, J.B., JR., R.K. Bowers JR., S.J. Suter, And C.E. Bock. 1999. Cassin's Sparrow (Peucaea cassinii) [online]. In: A. Poole, editor, The birds of North America online. Cornell Lab of Ornithology, Ithaca, NY. Available from: http://bna.birds.cornell.edu./bna/ species/471

Ford, P.L., AND G.R. McPherson. 1996. Ecology of fire in shortgrass prairie of the southern Great Plains. General Technical Report RM-GTR-285, USDA Forest Service, Albuquerque, NM.

Fuhlendorf, S.D., W.C. Harrell, D.M. Engle, R.G. Hamilton, C.A. Davis, and D.M. Leslie JR. 2006. Should heterogeneity be the basis for conservation? Grassland bird response to fire and grazing. Ecological Applications 16:1706-1716.
Goguen, C.B., And N.E. Mathews. 2000. Local gradients of cowbird abundance and parasitism relative to livestock grazing in a western landscape. Conservation Biology 14:1862-1869.

Grant, T.A., E.M. Madden, T.L. Shaffer, and J.S. Dockens. 2010. Effects of prescribed fire on vegetation and passerine birds in northern mixed-grass prairie. Journal of Wildlife Management 74:1841-1851.

Heirman, A.L., AND H.A. Wright. 1973. Fire in medium fuels of west Texas. Journal of Range Management 26:331-335.

Herkert, J.R., D.W. Sample, and R.E. Warner. 1996. Management of midwestern grassland landscapes for the conservation of migratory birds. General Technical Report NC-187, USDA Forest Service, St. Paul, MN.

JACKSON, A.S. 1969. A handbook for bobwhite quail management in the West Texas Rolling Plains. Bulletin No. 48, Texas Parks and Wildlife Department, Austin, TX.

JoHnson, D.H. 1999. Insignificance of statistical significance testing. Journal of Wildlife Management 63: 763-772.

2008. In defense of indices: the case of bird surveys. Journal of Wildlife Management 72:857-868.

Kirkpatrick, C., S. DeStefano, R.W. Mannan, and J. LLOYD. 2002. Trends in abundance of grassland birds following a spring prescribed burn in southern Arizona. Southwestern Naturalist 47:282-292.

Lloyd, J., R.W. Mannan, S. DeStefano, and C. KirkPATRICK. 1998. The effects of mesquite invasion on a southeastern Arizona grassland bird community. Wilson Bulletin 110:403-408.

LONG, A.M. 2010. Avian responses to prescribed burning in a shrub-encroached, semiarid grassland. Master's thesis, Emporia State University, Emporia, KS.

Long, A.M., W.E. Jensen, and R.S. Matlack. 2012. Effects of prescribed burning on avian nest survival in the southern Great Plains. Journal of Wildlife Management 76:899-906.

LowTHER, P.E. 1993. Brown-headed Cowbird (Molothrus ater). In: A. Poole, editor, The birds of North America online. Cornell Lab of Ornithology, Ithaca, NY.

Medina, E.J., AND F. Silva. 1990. Savannas of northern South America: a steady state regulated by water-fire interactions on a background of low nutrient availability. Journal of Biogeography 17: 403-413.

[NWS] National Weather Service Weather Forecast OFFICE. 2009. Observed weather reports-archived data. Available from: http://www.weather.gov

Peterjohn, B.G., And J.R. Sauer. 1999. Population status of North American grassland birds from North American Breeding Bird Survey, 1966-1996. Studies in Avian Biology 19:27-44.

Ransom, D., JR., R.R. Lopez, G.G. Schulz, and J.S. WaGNER. 2008. Northern Bobwhite habitat selection in relation to brush management in the rolling plains of Texas. Western North American Naturalist 68: 186-193.

R Development Core Team. 2011. R: a language and environment for statistical computing. R Foundation for Statistical Computing, Vienna, Austria.

Renwald, J.D., H.A. Wright, and J.T. Flinders. 1978. Effect of prescribed fire on bobwhite quail habitat in the rolling plains of Texas. Journal of Range Management 31:65-69. 
Reynolds, M.C., and P.R. Krausman. 1998. Effects of winter burning on birds in mesquite grassland. Wildlife Society Bulletin 26:867-876.

Roberts, A.J., C.W. Boal, D.B. Wester, S. RideoutHANZAK, AND H.A. WhitLaW. 2012. Grassland bird community responses to large wildfires. Wilson Journal of Ornithology 124:24-30.

Robinson, S.K., J.D. Brawn, S.F. Morse, and J.R. HerKert. 1999. Use of different habitats by breeding Brownheaded Cowbirds in fragmented midwestern landscapes. Studies in Avian Biology 18:52-61.

Roques, K.G., T.G. O'Connor, and A.R. Watkinson. 2001. Dynamics of shrub encroachment in an African savanna: relative influences of fire, herbivory, rainfall and density dependence. Journal of Applied Ecology 38:268-280.

Samson, F.B., And F.L. KnOpf. 1994. Prairie conservation in North America. BioScience 44:418-421.

Samson, FB., F.L. KNOPF, and W.R. Ostlie. 2004. Great Plains ecosystems: past, present, and future. Wildlife Society Bulletin 32:6-15.

Thomas, L., J.L. Laake, S. Strindberg, F.F.C. Maroues, S.T. Buckland, D.L. Borchers, D.R. Anderson, K.P. Burnham, S.L. Hedley, J.H. Pollard, et al. 2006. DISTANCE 5.0. Release 1. Research Unit for Wildlife Population Assessment, University of St. Andrews, United Kingdom.
Van Auken, O.W. 2000. Shrub invasions of North American semiarid grasslands. Annual Review of Ecology and Systematics 31:197-215.

ViCKERY, P.D., AND J.R. HERKERT. 2001. Recent advances in grassland bird research: where do we go from here? Auk 118:11-15.

Williams, R.J., G.D. Cook, A.M. Gill, and P.H.R. Moore. 1999. Fire regime, fire intensity and tree survival in a tropical savanna in northern Australia. Austral Ecology 24:50-59.

With, K.A., A.W. King, And W.E. Jensen. 2008. Remaining large grasslands may not be sufficient to prevent grassland bird declines. Biological Conservation 141:3152-3167.

Wright, H.A., AND A.W. BAILEy. 1982. Fire ecology in the United States and southern Canada. Wiley Interscience, New York, NY.

Yoder, J., D.M. Engle, M. Tilley, and S. Fuhlendorf. 2003. The economic logic of prescribed burning law and regulation. Journal of Range Management 56: 306-313.

Zimmerman, J.L. 1992. Density-independent factors affecting the avian diversity of the tallgrass prairie community. Wilson Bulletin 104:85-94.

Received 20 March 2014 Accepted 18 August 2014 